\title{
Variation in body size of ringed seals (Pusa hispida hispida) across the circumpolar Arctic: evidence of morphs, ecotypes or simply extreme plasticity?
} \author{
Olga Svetocheva ${ }^{11} \&$ Christian Lydersen ${ }^{1}$ \\ ${ }^{1}$ Norwegian Polar Institute, Fram Centre, Tromsø, Norway \\ ${ }^{2}$ Alaska Department of Fish and Game, Fairbanks, AK, USA \\ ${ }^{3}$ Department of Fisheries and Oceans, Vancouver, BC, Canada \\ ${ }^{4}$ Department of Bioscience, Marine Mammal Research, Aarhus University, Roskilde, Denmark \\ ${ }^{5}$ Fisheries and Oceans Canada, Winnipeg, MB, Canada \\ ${ }^{6}$ Fisheries and Oceans Canada, Yellowknife, NT, Canada \\ 7Environment and Climate Change Canada, Montreal, QB, Canada \\ ${ }^{8}$ Fisheries and Oceans Canada, Inuvik, NT, Canada \\ ${ }^{9}$ Greenland Institute for Natural Resources, Nuuk, Greenland \\ ${ }^{10}$ EMC Eco Marine Corp, Garthby, QB, Canada \\ ${ }^{11}$ Murmansk Marine Biological Institute, Russian Academy of Sciences, Murmansk, Russia
}

Kit M. Kovacs, ${ }^{1}$ John Citta, ${ }^{2}$ Tanya Brown, ${ }^{3}$ Rune Dietz, ${ }^{4}$ Steve Ferguson, ${ }^{5}$ Lois Harwood, ${ }^{6}$ Magali Houde, ${ }^{7}$ Ellen V. Lea, ${ }^{8}$ Lori Quakenbush, ${ }^{2}$ Frank Riget, ${ }^{9}$ Aqqalu Rosing-Asvid, ${ }^{9}$ Tom G. Smith, ${ }^{10}$ Vladimir Svetochev, ${ }^{11}$

\section{Abstract}

The ringed seal is a small phocid seal that has a northern circumpolar distribution. It has long been recognized that body size is variable in ringed seals, and it has been suggested that ecotypes that differ in size exist. This study explores patterns of body size (length and girth) and age-at-maturity across most of the Arctic subspecies' range using morphometric data from 35 sites. Asymptotic lengths varied from 113 to $151 \mathrm{~cm}$, with sites falling into five distinct size clusters (for each sex). Age-at-maturity ranged from 3.1 to 7.4 years, with sites that had early ages of sexual maturity generally having small length-at-maturity and small final body length. The sexes differed in length at some sites, but not in a consistent pattern of dimorphism. The largest ringed seals occurred in western Greenland and eastern Canada, and the smallest occurred in Alaska and the White Sea. Latitudinal trends occurred only within sites in the eastern Canadian Arctic. Girth (with length and season accounted for) was also highly variable but showed no notable spatial pattern; males tended to be more rotund than females. Genetic studies are needed, starting with the "giants" at Kangia (Greenland) and in northern Canada to determine whether they are genetically distinct ecotypes. Additional research is also needed to understand the ecological linkages that drive the significant regional size differences in ringed seals that were confirmed in this study, and also to understand their implications with respect to potential adaptation to climate change.
\end{abstract}

\section{Keywords}

Density-dependence; ecology; food availability; morphometry; pinniped; phocid seal

\section{Correspondence \\ Kit M. Kovacs, Norwegian Polar Institute, Fram Centre, PO Box 6606 Stakkevollan, NO-9296 Tromsø, Norway. E-mail: kit. kovacs@npolar.no}

\section{Abbreviations}

AIC: Akaike Information Criterion $\mathrm{Cl}$ : confidence interval

$\mathrm{CV}$ : coefficient of variation DIC: Deviance Information Criterion JAGS: Just Another Gibbs Sampler LPPD: log posterior predictive density MCMC: Markov Chain Monte Carlo SSE: sum of squared errors WAIC: Watanabe-Akaike Information Criterion or Widely Applicable Information Criterion

To access the supplementary material, please visit the article landing page

\section{Introduction}

Body size is a significant determinant of an organism's biological role, as it is a key underlying parameter in a wide variety of physiological, anatomical, ecological and life history parameters (e.g., Kleiber 1975; Peters 1983; Calder 1996; Sibly \& Brown 2007). Interspecifically, body size has been linked to metabolic rate, movement efficiency, home range size, longevity, growth rate, production rate and a host of other biological parameters. Intraspecifically, latitudinal gradients in body size have been demonstrated, which are thought to be related to both surface to volume efficiency (for thermoregulation) and the ability to store more energy (usually lipids, i.e., fat) to survive in areas 
with short growing seasons (Lindstedt \& Boyce 1985; Blackburn \& Gaston 1994; Blackburn et al. 1999; Gaston 2000; Luque \& Ferguson 2010). However, intraspecific variation in body size patterns is poorly explored despite ecotypes and morphs differing in body size being relatively common features within species, many of which are thought to be linked to various environmental gradients across species' ranges. By definition, an ecotype (sometimes called an ecospecies) is a genetically distinct geographic variety that is genotypically adapted to specific environmental conditions (e.g., Turesson 1922; Lowry 2012). However, size morphs are also possible within a population among individuals that do not differ from one another genetically (with respect to genes controlling body size), and morph frequency can change through time depending on prevailing environmental conditions. Morphs occupy the same habitat at the same time and generally belong to a panmictic population.

The ringed seal is a broadly distributed phocid seal species that occurs as five recognized subspecies: the Arctic ringed seal (Pusa hispida hispida); the Okhotsk ringed seal (P. h. ochotensis); the Baltic ringed seal (P. h. botnica); the Ladoga seal (P. h. ladogensis); and the Saimaa seal (P. $h$. saimensis; Lowry 2016). All ringed seal subspecies are tightly affiliated with ice, and most ringed seals give birth to their pups in snow lairs built on the top of sea ice or lake ice. The Arctic subspecies also uses sea ice as a latespring moulting platform and rests on sea ice throughout the year. This subspecies also does a lot of its feeding sympagically, consuming a variety of ice-affiliated prey (e.g., Bengtsson et al. 2020). Hauling out on shorelines (or rocks exposed at low tide) is rare in $P$. $h$. hispida, although it does occur in some areas at low tide during the ice-free season (e.g., Labrador), and is now occurring more regularly in areas where sea ice declines have been marked in recent decades (e.g., Lydersen et al. 2017). The Arctic ringed seal ( $P . h$. hispida) occupies the largest range of the five ringed seal subspecies, occurring throughout the circumpolar Arctic. Body size varies widely within this subspecies, as does age of maturation (McLaren 1958, 1993; Mansfield 1967; Tikhomirov 1971; Smith 1973; Fedoseev 1975). Patterns of sexual dimorphism in this subspecies also range from being monomorphic to dimorphic in both directions, with larger males being the most common pattern but females are largest in some regions (e.g., Lydersen \& Gjertz 1987; McLaren 1993; Ferguson et al. 2018).

Genetics studies of Arctic ringed seals suggest that the subspecies exhibits high levels of gene flow across their range (Davis et al. 2008; Martinez-Baker et al. 2013). These findings are challenging to reconcile with reports of variable body size as well as differences in some other morphological traits (e.g., thicker, longer coat) by area/ habitat type (Fedoseev 1975; Finley et al. 1983; McLaren
1993; Rosing-Asvid 2010). The most systematic reports of differences in ringed seal sizes are between land-fast ice (also called shore-fast ice) breeding seals and offshore drift-ice breeding seals, the latter reportedly being much smaller (Fedoseev 1975; Finley et al. 1983; McLaren 1993; Von Duyke et al. 2020). However, quite broadly, there appear to be differences in the size reached at the age of sexual maturity from area to area for ringed seals. McLaren (1993) analysed growth curves for Arctic ringed seals from several areas, found differences among populations and suggested that variability in the size of ringed seals may be greater in more extreme Arctic environments. Ferguson et al. (2018) reported differences in body sizes of ringed seals with larger body size, slower growth and very late maturation in a northern group compared to a southern group within the eastern Canadian Arctic (though they state that this was not a strict latitudinal gradient). The north was characterized by more land-fast ice, more multi-year ice, greater snow depth, colder temperatures and greater sea-ice concentrations in the spring breeding season. It is somewhat counterintuitive that in what is believed to be preferred habitat, with more stable sea ice, seals grow more slowly and take longer to reach age at maturity. However, most in-depth analyses of growth tend to focus on only one region at a time (e.g., Krafft et al. 2007; Crawford et al. 2015; Harwood et al. 2020) or they extend across subspecies boundaries (Fedoseev 1975; McLaren 1993), leaving potential within-subspecies patterns largely unexplored.

The present study compiles ringed seal's body size data across much of the Arctic subspecies range, incorporates recent data not previously published from areas where previous studies have been conducted and uses improved analytical methods (averaged growth models) to definitively explore patterns of body size in Arctic ringed seals. It examines and compares asymptotic lengths from 35 different sampling locations. To further explore regional patterns in size, patterns in girth were also explored from 32 sites after controlling for length and time of year (see Ryg et al. 1990; Young \& Ferguson 2013).

\section{Methods}

Data on ringed seal growth and age-at-maturity were compiled from 35 sampling locations (collected independently by researchers from multiple jurisdictions) between 1978 and 2017, encompassing much of the circumpolar Arctic (Table 1, Fig. 1). These data were from a variety of national harvest-monitoring programmes or specific studies conducted on ringed seals that did collection programmes, so data cover different periods and seasons in the different regions. Data from all regions included measurements of standard (straight-line, belly up, and tip 
Table 1 Sample sizes for ringed seals in this study by location. Numbers in parentheses are sample sizes (those in italics indicate that the minimum sample size set for a particular analysis was not reached). Data for age and length at maturity were only available for seven sites.

\begin{tabular}{|c|c|c|c|c|c|c|c|c|c|}
\hline \multirow[t]{2}{*}{$\begin{array}{l}\text { Map } \\
\text { key }\end{array}$} & \multirow[t]{2}{*}{ Location } & \multirow[t]{2}{*}{ Years } & \multirow[t]{2}{*}{ Months } & \multirow[t]{2}{*}{ Region } & \multicolumn{2}{|c|}{$\begin{array}{l}\text { Asymptotic } \\
\text { length }\end{array}$} & \multicolumn{2}{|c|}{ Residual girth } & \multirow{2}{*}{$\begin{array}{c}\begin{array}{c}\text { Age/length at } \\
\text { maturity }\end{array} \\
\text { (F only) }\end{array}$} \\
\hline & & & & & $\mathrm{F}$ & M & $\mathrm{F}$ & M & \\
\hline 1 & Gambell & 2009-2012 & Jun-Mar & Alaska & $3(2)$ & $18(9)$ & 2 & 10 & \\
\hline 2 & Little Diomede & 2002-2012 & Nov-Jun & Alaska & $3(1)$ & $12(5)$ & 2 & 7 & \\
\hline 3 & Hooper Bay & 2004-2012 & Nov-May & Alaska & $27(3)$ & $34(5)$ & 8 & 15 & \\
\hline 4 & Shishmaref & 2000-2012 & May-Dec & Alaska & $54(23)$ & $154(71)$ & 30 & 93 & 113 \\
\hline 5 & Utqiaġvik & 2005-2011 & Jun-Oct & Alaska & $5(5)$ & $8(4)$ & 5 & 6 & \\
\hline 6 & Sachs Harbour & 1992-2017 & Jun-Sep & W. Canada & $107(51)$ & $119(52)$ & 42 & 50 & \\
\hline 7 & Ulukhaktok & 1992-2016 & May-Oct & W. Canada & $746(488)$ & $1011(668)$ & 805 & 1075 & 1058 \\
\hline 8 & Minto & 1992-99 & May-Aug & W. Canada & $160(142)$ & $320(289)$ & 155 & 308 & \\
\hline 9 & Arviat & 2003-2015 & Apr-Nov & Hudson Bay & $224(124)$ & $214(104)$ & 141 & 135 & 51 \\
\hline 10 & Chesterfield Inlet & 1999-2010 & Jan-Dec & Hudson Bay & $32(21)$ & $30(17)$ & 24 & 15 & \\
\hline 11 & Sanikiluaq & 2003-2015 & Jan-Dec & Hudson Bay & $237(93)$ & $380(131)$ & 121 & 176 & 202 \\
\hline 12 & Gjoa Haven & 2004-2015 & May-Oct & E. Canada & $19(8)$ & $17(3)$ & 11 & 5 & \\
\hline 13 & Resolute & 2004-2014 & Apr-Nov & E. Canada & $63(24)$ & $114(32)$ & 35 & 58 & \\
\hline 14 & Kugaaruk & 2012-15 & May-Nov & E. Canada & $36(16)$ & $33(16)$ & 13 & 12 & 47 \\
\hline 15 & Repulse Bay & 2006-09 & Jan-Dec & E. Canada & $40(20)$ & $57(25)$ & 24 & 29 & \\
\hline 16 & Eureka & 1994 & May-Jun & E. Canada & $8(7)$ & $6(2)$ & 7 & 5 & \\
\hline 17 & Arctic Bay & 1993-2009 & Apr-Sep & E. Canada & $43(12)$ & $68(29)$ & 23 & 41 & \\
\hline 18 & Grise Fiord & 2003-08 & Sep-Oct & E. Canada & $13(3)$ & $20(5)$ & 4 & 7 & \\
\hline 19 & Igloolik & 2009 & Nov-May & E. Canada & $6(4)$ & $9(3)$ & 4 & 5 & \\
\hline 20 & Pond Inlet & 2004-2015 & Aug-Oct & E. Canada & $10(4)$ & $18(3)$ & 7 & 6 & \\
\hline 21 & Pangnirtung & 1990-2015 & Jan-Dec & E. Canada & $140(18)$ & $169(23)$ & 46 & 62 & 96 \\
\hline 22 & Nachvak & $2008-2010$ & Aug-Sep & Labrador & $17(14)$ & $11(9)$ & 15 & 10 & \\
\hline 23 & Saglek & 2008-2011 & Aug-Sep & Labrador & $17(10)$ & $16(12)$ & 12 & 13 & \\
\hline 24 & Okak & 2008-2010 & Aug-Oct & Labrador & $16(9)$ & $9(5)$ & 12 & 7 & \\
\hline 25 & Nain & 1998-2017 & Jun-Dec & Labrador & $51(12)$ & $34(14)$ & 10 & 4 & \\
\hline 26 & Thule (Qaanaaq) & 1984-2012 & Apr-Nov & W. Greenland & $121(26)$ & $152(29)$ & 12 & 10 & \\
\hline 27 & Upernavik & 1978-1987 & May-Oct & W. Greenland & $16(2)$ & $41(3)$ & 5 & 8 & \\
\hline 28 & Disko Bay & 1982-2012 & Oct-May & W. Greenland & $74(2)$ & $110(2)$ & 4 & 4 & \\
\hline 29 & Uummannaq & 2010-2012 & Apr-Aug & W. Greenland & 77 (3) & $99(3)$ & 0 & 0 & \\
\hline 30 & Kangia & 2013-2017 & Nov-May & W. Greenland & $57(19)$ & $44(10)$ & 0 & 0 & \\
\hline 31 & Kong Oscars Fjord & 1985 & May-Sep & E. Greenland & $10(8)$ & $9(6)$ & 9 & 8 & \\
\hline 32 & Ittogqortoormiit & 1986-2012 & Mar-Jun & E. Greenland & $118(17)$ & $146(23)$ & 19 & 22 & \\
\hline 33 & Svalbard & $1981-2004$ & Apr-Jul & Svalbard & $217(140)$ & $206(103)$ & 172 & 145 & 247 \\
\hline 34 & White Sea & 1983-2013 & Jan-Apr & Russia & $28(8)$ & $30(3)$ & 13 & 11 & \\
\hline 35 & Kara Sea & 1984-2005 & Mar-Apr & Russia & $21(1)$ & $29(13)$ & 2 & 14 & \\
\hline
\end{tabular}

of nose to tip of tail) length. Some also included measurements of girth and reproductive status (Table 1). Age was determined by counting rings in cementum and/or dentine in extracted teeth (usually canine teeth), following Dietz et al. (1991). More details on collections by region are provided in the Supplementary material.

\section{Estimating asymptotic length}

Sampling locations varied greatly in the number of samples available for fitting growth models. To determine the sample size needed to fit reliable growth models of asymptotic length, the eight largest data sets (Arviat, Avanersuaq/Thule, Ittoqqortoormiit/Scoresby Sound, Minto, Pangnirtung, Sanikiluaq, Svalbard and Ulukhaktok) were subsampled, and models were fitted to data sets of various sizes (see Supplementary material for details). Growth models generally provided a lower CV than the corresponding mean for animals over 10 years of age, which improved our ability to detect statistically significant differences among sites or between sexes. However, growth models generally required sample sizes of at least 60 seals sampled at random to ensure that confidence limits encompassed the true mean in at least $95 \%$ of cases 


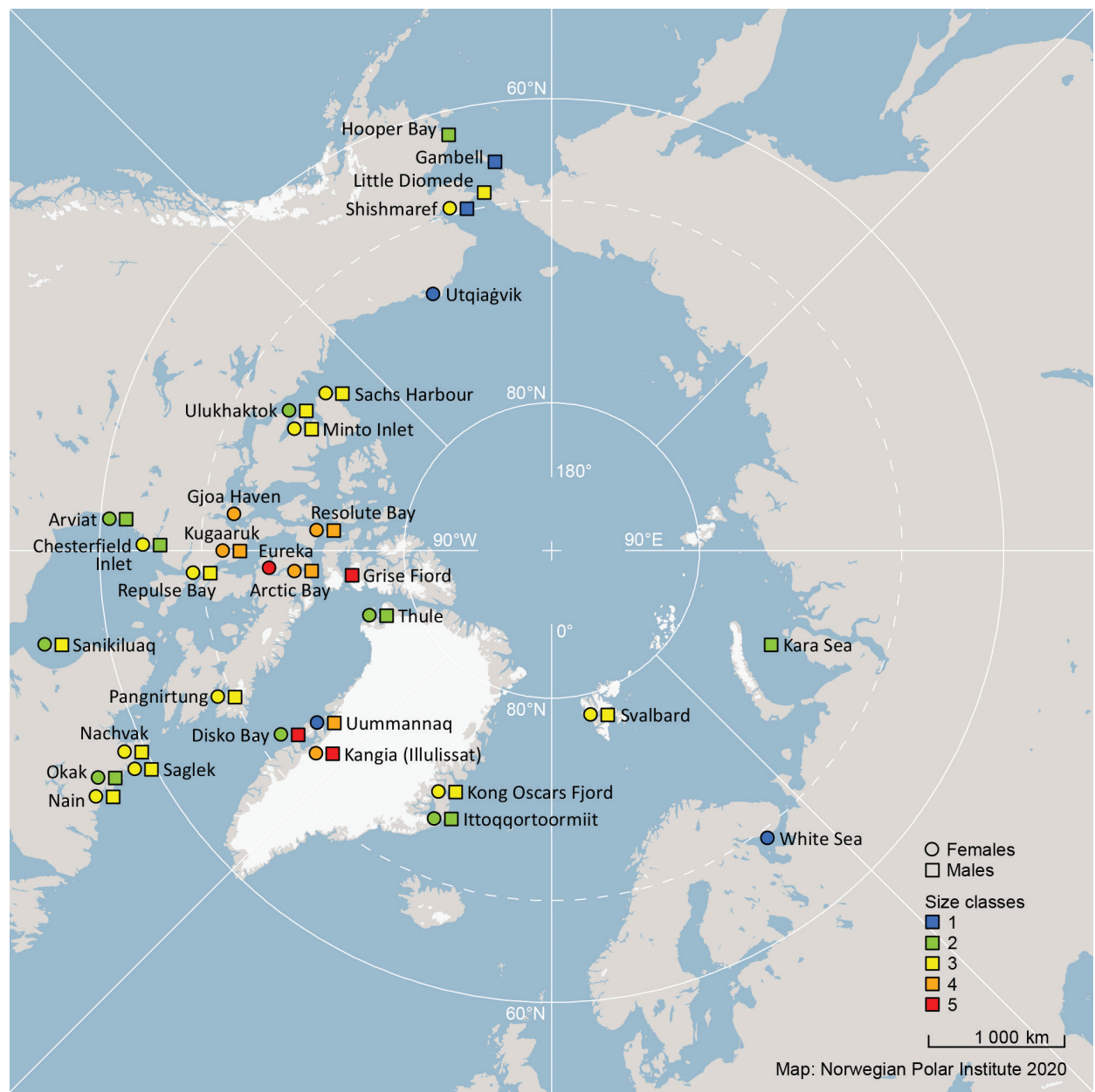

Fig. 1 Ringed seal length size classes for adult male and adult female ringed seals by sampling location.

(Supplementary Table S1). When calculating a mean length of seals $\geq 10$ years of age, $95 \%$ confidence limits encompassed the true mean in over $95 \%$ of cases with as few as two samples (Supplementary Table S2); however, this is at the cost of having a relatively high CV and large mean residuals. We decided to calculate a mean length of seals $\geq 10$ years of age when there were $\geq 5$ but $<60$ samples for a given site and sex. Differences in asymptotic length less than approximately $3 \mathrm{~cm}$ among sites were deemed unreliable for both means and modelled lengths, as simulations suggested they could arise from sampling error (Supplementary Tables S1, S2). Based upon these findings, growth models were used to estimate asymptotic length only when sample sizes were $\geq 60$ samples for a given site and sex; mean length of seals $\geq 10$ years of age was used to estimate asymptotic length where there are at least five samples for a given site and sex (Table 2). There were 35 sites with two sexes for 70 site/sex comparisons; models were used in 26 instances (37\%), and mean length of
Table 2 Models used to estimate asymptotic length $\left(L_{\infty}\right)$ of ringed seals.

\begin{tabular}{lcc}
\hline Growth model name & Equation & $\begin{array}{c}\text { Number } \\
\text { parameters }\end{array}$ \\
\hline $\begin{array}{l}\text { Logistic model (Panik 2014) } \\
\text { Gompertz model (Quinn \& }\end{array}$ & $L_{t}=L_{\infty} /\left(1+\beta e^{-k\left(t-t_{0}\right)}\right)$ & 5 \\
$\begin{array}{l}\text { Deriso 1999) } \\
\text { Generalized von Bertalanffy } \\
\text { model (Pauly 1981; Quinn \& }\end{array}$ & $L_{t}=L_{\infty} e^{-\alpha\left(e^{-k\left(t-t_{0}\right)}\right)}$ & 5 \\
$\begin{array}{l}\text { Deriso 1999) } \\
\text { Weibull model (Panik 2014) }\end{array}$ & $L_{t}\left[1-e^{-k\left(t-t_{0}\right)}\right]^{p}$ & 5 \\
$\begin{array}{l}\text { Schnute-Richards model } \\
\text { (Schnute \& Richards 1990; } \\
\text { Quinn \& Deriso 1999) }\end{array}$ & $L_{t}=L_{\infty}\left(1+\beta e^{-\left(k\left(t-t_{0}\right)^{m}\right)}\right.$ & 6 \\
\hline
\end{tabular}

${ }^{a} L_{t}$ is the length of a seal at age $t$. Parameter $t_{0}$ is the age at which a seal is assumed to have zero length; based upon the work of McLaren (1993), $t_{0}$ was assumed to equal $-0.6 \mathrm{I}$. Parameter $\mathrm{K}$ is the growth rate and $\beta, P$ and $m$ are dimensionless shape parameters. The number of parameters includes those used for estimating error terms in the model (e.g., standard deviation). 
animals over 10 years of age were used in 34 instances $(49 \%, n \geq 5)$. Ten sites ( $14 \%$ ) had insufficient numbers of older individuals and were used only in dimensional comparisons (girth adjusted for body length).

Regional data sets (see Table 1) supported different growth models, and multiple growth models were often supported within a region, so a multi-model inference method was employed to estimate a model-averaged asymptotic length (see Supplementary material for more details). Five growth models were used for multi-model inference (see Table 2): (1) the logistic model (e.g., Panik 2014); (2) the Gompertz model (Quinn \& Deriso 1999); (3) the generalized von Bertalanffy model (Pauly 1981; Quinn S Deriso 1999); (4) a Weibull model (Panik 2014); and (5) the Schnute-Richards model (Schnute 8 Richards 1990; Quinn \& Deriso 1999). These are commonly used growth models in studies of asymptotic length and represent a range of complexity, requiring the fitting of between three and five parameters (Table 2), not including Bayesian error terms. The von Bertalanffy model (von Bertalanffy 1938) was also considered, but it was never a parsimonious model and was, therefore, dropped from further consideration.

Multi-model inference relies on information criteria that balance the fit of a model with the level of model complexity (Burnham \& Anderson 2003; Katsanevakis 2006). Model fit is typically based upon the likelihood of the model, while model complexity is typically based upon the number of parameters. DIC is the information criterion used for most Bayesian analyses (Gelman et al. 2014). In practice, the number of effective parameters is often difficult to calculate for hierarchical models, and DIC is known for selecting models that are overly complicated (Hooten et al. 2015; Vehtari et al. 2017). Alternative information criteria, such as the WAIC (Watanabe 2010; Vehtari et al. 2017), are, therefore, becoming more common. WAIC is known to provide a better estimate of the number of effective parameters, especially for hierarchical models; for more information, see Hooten et al. (2015) and Vehtari et al. (2017).

Calculations of WAIC were done according to the following formula:

$$
\mathrm{WAIC}=-2 L P P D+2 P,
$$

where $L P P D$ is the log posterior predictive density and $P$ is a measure of model complexity. When calculating $L P P D$, for each observation (i.e., each record of length or girth), the likelihood of each MCMC sample is calculated, given that observation. Subsequently, mean likelihood is calculated, log transformed and then summed across all observations. $P$ is calculated for each observation (i.e., each record of length or girth) as the log likelihood of each MCMC sample given that observation. Sample variance is then calculated as the log likelihoods for each observation, which is then summed (see Hooten et al. 2015).

WAIC functions like AIC in that smaller scores indicate a more parsimonious model. As with AIC and DIC, differences in WAIC scores ( $\triangle$ WAIC) can be calculated to determine the best approximating model, and weights $(w)$ for use in model averaging (e.g., Burnham $\delta$ Anderson 2003) can be calculated. The weighting for model $i$ is

$$
w_{i}=\frac{e^{--\frac{1}{2} \Delta w A I C_{i}}}{\sum_{i=1}^{N} e^{--\frac{1}{2} \Delta w A I C_{i}}} .
$$

When model averaging a growth parameter $(\beta)$, the parameter estimate from each model is multiplied by that model's weight and then these are summed:

$$
\beta_{\text {mean }}=\sum_{i=1}^{N} \beta_{i} w_{i}
$$

Model averaging parameters allow for the same set of growth models to be applied to each region, letting the data determine how much weight is given to each model.

All statistical analyses were done in $\mathrm{R}$ ( $\mathrm{R}$ Core Team 2020) using packages that interface $R$ with the programme JAGS, a programme designed for the analysis of Bayesian models using MCMC methods. Herein, "jagsUI" (Kellner 2019) and "rjags" (Plummer 2019) programmes are used to specify MCMC simulations from R. WAIC values were calculated using the "loo" package (Vehtari et al. 2018).

Models were fitted using seals $\geq 1$ year of age. Four MCMC chains were simulated, each with a 20 000-sample burn-in; across all four chains, 400000 iterations were retained for computing statistics from the growth models. Each simulation was checked for convergence using the Gelman-Rubin convergence statistic (Gelman et al. 2003). Models were fitted for each sex, within each region. Statistical tests and 95\% confidence limits were calculated in R using the MCMC sample outputs.

For sites with $\geq 5$ samples and $<60$ samples, asymptotic length was estimated as the average length of seals $\geq 10$ years of age, and confidence limits were based upon $t$-distributions. Although the estimate of asymptotic length from small samples is less reliable, $t$-distributions provided adequate coverage of $95 \%$ confidence limits (Supplementary Table S2).

To help identify regional patterns in asymptotic length, sites were assigned to clusters of similar asymptotic length using a k-means clustering algorithm (Hartigan \& Wong 1979). This clustering approach minimizes the SSE for a given number of clusters. Total SSE declines as more centroids (clusters) are fitted to the data. We sequentially fit 
2 to $n_{\text {sites }-1}$ centroids to the data until the number of centroids explained about $95 \%$ of the total variation in the data.

\section{Residual girth}

Girth generally increases with length, so the residual of this relationship was used to identify seals that had more or less girth than expected given their length, as this may be another attribute of shape related to the presence of ecotypes. To assess girth relative to length, linear and quadratic models were fitted to girth-at-length data for seals $\geq 6$ years of age, pooled across sampling locations, for each sex separately. Because girth varies seasonally in ringed seals, month of sampling was used as a factor covariate, and residuals were used to assess girth relative to length, while controlling for month of sampling.

\section{Age and length at maturity}

The average age-at-maturity was defined as the age at which $50 \%$ of females were classified as being mature, on the basis of the presence of corpora lutea in the ovaries, usually in combination with distended uterine horn(s) or the presence of a foetus (when uteri were examined). The average length-at-maturity was defined as the length at which $50 \%$ of females were mature. This parameter was calculated using a probit regression in $\mathrm{R}$ ( $\mathrm{R}$ Core Team 2020; see Table 1). Data were available to calculate age and length at maturity for seven study sites spread west-to-east between Alaska and Svalbard (Table 1).

\section{Results}

\section{Asymptotic length}

Model-averaged estimates of asymptotic length (Table 3) clustered into five groups for both males and females (Table 4); there were significant size differences between sexes at some sites, so males and females are analysed and presented separately. Five clusters explained 94.8\% of the variability for both females and males. Length steps between adjacent clusters averaged $8.9 \mathrm{~cm}$ for females and 9.2 for males, while minimum differences in asymptotic lengths by sampling location averaged $3.8 \mathrm{~cm}$ for females and $3.3 \mathrm{~cm}$ for males. The largest and smallest cluster means differed by $35.7 \mathrm{~cm}$ for females and 36.8 $\mathrm{cm}$ for males.

The largest female ringed seals (clusters 4 and 5) were located in the central and eastern Canadian High Arctic, western Greenland and Svalbard (Fig. 2). The smallest females (cluster 1) were located in Alaska and the White Sea. The pattern for males was similar, with the largest males (clusters 4 and 5) being also found in the central and eastern Canadian High Arctic and Greenland (Fig. 2) and the smallest males in Alaska. There was no relationship between latitude and length for either sex (females, $p=0.09$; males, $p=0.26$ ).

Males and females fell into similar sex-length clusters at 16 of 23 sites $(70 \%)$, while they fell into different sexlength clusters at seven sites (Fig. 1). Out of 23 statistical comparisons of sex and length, only six sites had males and females that were significantly different $(p \leq 0.05)$; males were significantly larger than females in Ulukhaktok, Sanikiluaq, Repulse Bay, Qeqertarsuaq/ Disko Bay and Uummannaq; however, females were significantly larger than males in Svalbard.

\section{Girth (given length)}

After controlling for the month of sampling, the relationship between length and girth was best approximated using a linear model for females $(\triangle \mathrm{AIC}=2.0)$ and a curvilinear model for males ( $\triangle \mathrm{AIC}=28.7$ ). On average, females had 0.63 (standard error $=0.02$ ) $\mathrm{cm}$ more girth for each $\mathrm{cm}$ of length. For males, girth increased with length, but the rate of increase declined as length increased.

Patterns in average girth residuals by location aggregated into four clusters for females and five for males (Table 5). The four clusters explained $96.3 \%$ of the variability for females and the five clusters explained $96.4 \%$ of the variability for males. Males and females fell into similar (within the same or adjacent grouping) sex-girth clusters at 17 sites, while the sexes fell into different cluster numbers at nine sites. Seals falling into the highest girth category (cluster 5 for males) occurred in Russian, Greenland, eastern Canada and western Canada; only Alaska was dominated by small girth categories. Girth residuals differed markedly between some adjacent sites, such as Ulukhaktok versus Minto (sampled in the same season) and Arctic Bay versus Pond Inlet.

\section{Age/length at maturation}

Seven locations had sufficient data to estimate ageand length-at-maturity for female ringed seals (Table 6). Age-at-maturity (mean $\pm 95 \%$ CI) was youngest at Shishmaref $(3.1 \pm 0.88$ years $)$ and oldest at Ulukhaktok (7.4 \pm 0.40 years). Within eastern Canada, northern sampling locations (i.e., Pangnirtung and Kugaaruk) had older ages of maturity than southern locations in Hudson Bay (Table 6). However, there was no obvious pattern with latitude outside eastern Canada. The northernmost location for which there were maturity data was Svalbard $\left(79.0^{\circ} \mathrm{N}\right)$, which had a low/mid-ranging age-at-maturity $(3.9 \pm 0.42$ years $)$. 
Table 3 Asymptotic lengths $\left(L_{\infty}\right)$ and $95 \% \mathrm{Cls}(\mathrm{cm})$ as estimated from averaged growth models (Method $=$ Model) or by taking the average length of seals $\geq 10$ years of age (Method $=$ Mean). Dashes denote insufficient data.

\begin{tabular}{|c|c|c|c|c|c|}
\hline \multirow[t]{2}{*}{ Location } & \multicolumn{2}{|c|}{ Females } & \multicolumn{2}{|c|}{ Males } & \multirow[t]{2}{*}{$p_{\operatorname{sex}^{a}}^{a}$} \\
\hline & Method & $L_{\infty}$ & Method & $L_{\infty}$ & \\
\hline Gambell & - & - & Mean $(\mathrm{x})$ & $109.6(98.7-120.5)$ & - \\
\hline Little Diomede & - & - & Mean $(\mathrm{x})$ & $131.152(95.6-166.8)$ & - \\
\hline Hooper Bay & - & - & Mean $(\mathrm{x})$ & $125.2(114.4-135.4)$ & - \\
\hline Shishmaref & Mean $(x)$ & $126.4(116.9-135.8)$ & Model & $115.9(112.6-120.8)$ & 0.079 \\
\hline Utqiaġvik & Mean $(x)$ & $116.4(98.6-134.2)$ & Mean $(\mathrm{x})$ & - & - \\
\hline Sachs Harbour & Model & $128.0(119.6-142.1)$ & Model & $135.2(128.1-147.0)$ & 0.15 \\
\hline Ulukhaktok & Model & $123.0(122.22-123.7)$ & Model & $127.6(127.0-128.2)$ & $<0.001$ \\
\hline Minto & Model & $131.0(128.8-134.4)$ & Model & $130.2(129.4-131.2)$ & 0.318 \\
\hline Arviat & Model & $120.0(118.0-122.2)$ & Model & $120.0(118.5-121.6)$ & 0.493 \\
\hline Chesterfield Inlet & Mean $(x)$ & $128.1(119.4-136.8)$ & Mean $(\mathrm{x})$ & $124.8(118.2-131.4)$ & 0.53 \\
\hline Sanikiluaq & Model & $125.1(123.4-127.6)$ & Model & $127.9(127.0-128.9)$ & 0.021 \\
\hline Gjoa Haven & Mean $(x)$ & $142.6(120.8-164.5)$ & Mean $(\mathrm{x})$ & - & - \\
\hline Resolute & Model & $140.5(137.2-144.4)$ & Model & $141.6(139.0-144.7)$ & 0.308 \\
\hline Kugaaruk & Mean $(x)$ & $137.4(127.5-147.2)$ & Mean $(\mathrm{x})$ & $144.4(137.8-151.0)$ & 0.219 \\
\hline Repulse Bay & Mean $(x)$ & $126.9(122.1-131.7)$ & Mean $(\mathrm{x})$ & $134.6(128.8-140.5)$ & 0.041 \\
\hline Eureka & Mean $(x)$ & $151.0(100.2-201.8)$ & Mean $(\mathrm{x})$ & - & - \\
\hline Arctic Bay & Mean $(x)$ & $141.2(132.4-150.1)$ & Model & $140.0(137.6-142.6)$ & 0.465 \\
\hline Grise Fiord & - & - & Mean (x) & $147.7(121.3-174.2)$ & - \\
\hline Igloolik & - & - & - & - & - \\
\hline Pond Inlet & - & - & - & - & - \\
\hline Pangnirtung & Model & $133.5(129.8-138.1)$ & Model & $134.3(131.0-138.2)$ & 0.373 \\
\hline Nachvak & Mean $(x)$ & $126.5(120.0-133.1)$ & Mean $(x)$ & $132.1(126.4-137.8)$ & 0.169 \\
\hline Saglek & Mean $(x)$ & $128.6(123.1-134.1)$ & Mean $(x)$ & $129.3(121.9-136.6)$ & 0.875 \\
\hline Okak & Mean $(x)$ & $122.2(115.2-129.2)$ & Mean $(x)$ & $121.4(112.0-130.8)$ & 0.471 \\
\hline Nain & Mean $(x)$ & $127.3(120.0-134.6)$ & Mean $(x)$ & $132.8(126.9-138.7)$ & 0.212 \\
\hline Thule (Qaanaaq) & Model & $122.5(120.3-125)$ & Model & $123.2(120.2-128.3)$ & 0.407 \\
\hline Upernavik & - & - & - & - & - \\
\hline Disko Bay & Model & $122.3(110.3-137.9)$ & Model & $150.8(134.3-174.5)$ & 0.007 \\
\hline Uummannaq & Model & $113.2(109.7-117.7)$ & Model & $144.4(136.3-155.2)$ & $<0.001$ \\
\hline Kangia & Mean $(x)$ & $144.8(139.8-149.8)$ & Mean $(x)$ & $150.1(140.8-159.4)$ & 0.287 \\
\hline Kong Oscars Fjord & Mean $(x)$ & $126.5(121.2-131.8)$ & Mean $(\mathrm{x})$ & $132.0(126.0-138.0)$ & 0.114 \\
\hline Ittoqqortoormiit & Model & $120.0(116.9-124.9)$ & Model & $122.8(119.4-128.4)$ & 0.159 \\
\hline Svalbard & Model & $132.1(130.6-134.2)$ & Model & $128.4(127.3-129.6)$ & $<0.001$ \\
\hline White Sea & Mean $(x)$ & $116.3(110.1-122.4)$ & Mean $(\mathrm{x})$ & - & - \\
\hline Kara Sea & Mean $(x)$ & - & Mean $(x)$ & $118.8(115.6-122.0)$ & - \\
\hline
\end{tabular}

aThe probability that sexes differ by size. Statistically significant differences in asymptotic length are in boldface.

Length-at-maturity (mean $\pm 95 \% \mathrm{CI}$ ) was shortest at Arviat $(102.7 \pm 2.9 \mathrm{~cm})$ and longest at Kugaaruk (1 $15.3 \pm$ $0.89 \mathrm{~cm}$; Table 6). Within eastern Canada, northern sampling locations (i.e., Pangnirtung and Kugaaruk) had larger seals than at southerly locations (e.g., Hudson Bay; Table 6). However, as with age-at-maturity, there was no obvious pattern with latitude outside eastern Canada. The northernmost site for which there were length-at-maturity data in this study was Svalbard $\left(79.0^{\circ} \mathrm{N}\right)$, which had a length-of-maturity $(107.7 \pm 3.34$ years $)$ that fell in the middle of the range. Age-at-maturity was correlated with length at maturity, with seals being smaller at sites where they matured younger (Pearson's $R=0.64$ ), with the notable exception of Ulukhaktok, a site with the oldest age-at-maturity but where seals fall into small and mid-length groupings. Overall, length-at-maturity was strongly correlated with estimated final body size (Pearson's $R=0.75)$.

\section{Discussion}

This study demonstrates clear differences in asymptotic lengths of ringed seals within and between regions across a large geographic scale encompassing most of the ringed 
Table 4 Cluster assignments and mean cluster values for asymptotic length $\left(L_{\infty}\right)$ by sampling location and sex. Dashes denote when $L_{\infty}$ was not estimated because there were fewer than five seals at least 10 years of age. Five clusters explained $94.8 \%$ of the variation in mean asymptotic length for both females and males.

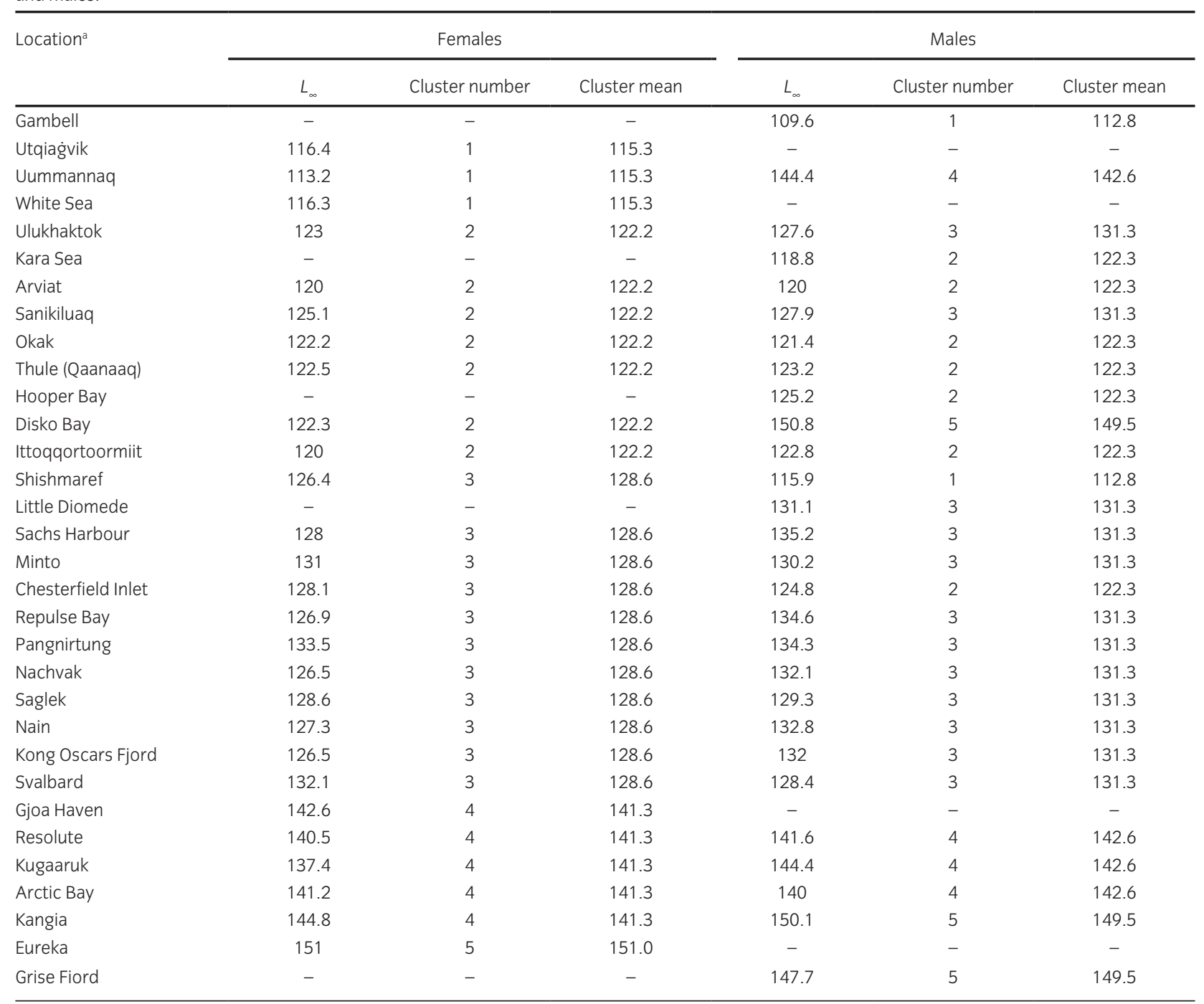

a Sampling locations are ordered by the asymptotic length for females.

seal's circumpolar range. The largest seals occur in western Greenland (where local experts suggest Kangia is the source of the large animals in this region) and north-eastern Canada (and possibly in the Kara Sea). The smallest seals were found in the White Sea and in the Alaska. There was no clear, consistent trend with latitude (or with longitude) except in the eastern Canadian Arctic. A variety of regions at roughly similar latitudes (e.g., western Canada, Labrador and eastern Greenland) had seals of generally similar size, but neighbouring inlets within those same regions in some cases had seals of markedly different sizes. Variable body size in ringed seals has been noted in the past, in both studies across populations and between subspecies (e.g., Fedoseev 1975; McLaren 1993; Holst \& Stirling 2002). The suggested drivers of this variability include: genetics; relative degree stability of breeding habitat; predator avoidance; food availability (particularly in early growth phases); density-dependent effects (levels of competition) arising from harvesting; ice conditions or more general aspects of climate variability/ change and combinations of the above (Holst et al. 1999; Harwood et al. 2000; Holst \& Stirling 2002; Harwood, Smith \& Auld 2012; Harwood, Smith, Melling et al. 2012; Pilford et al. 2014; Ferguson et al. 2018).

Only two studies have been conducted on genetic stock/population discreteness across the range of the 


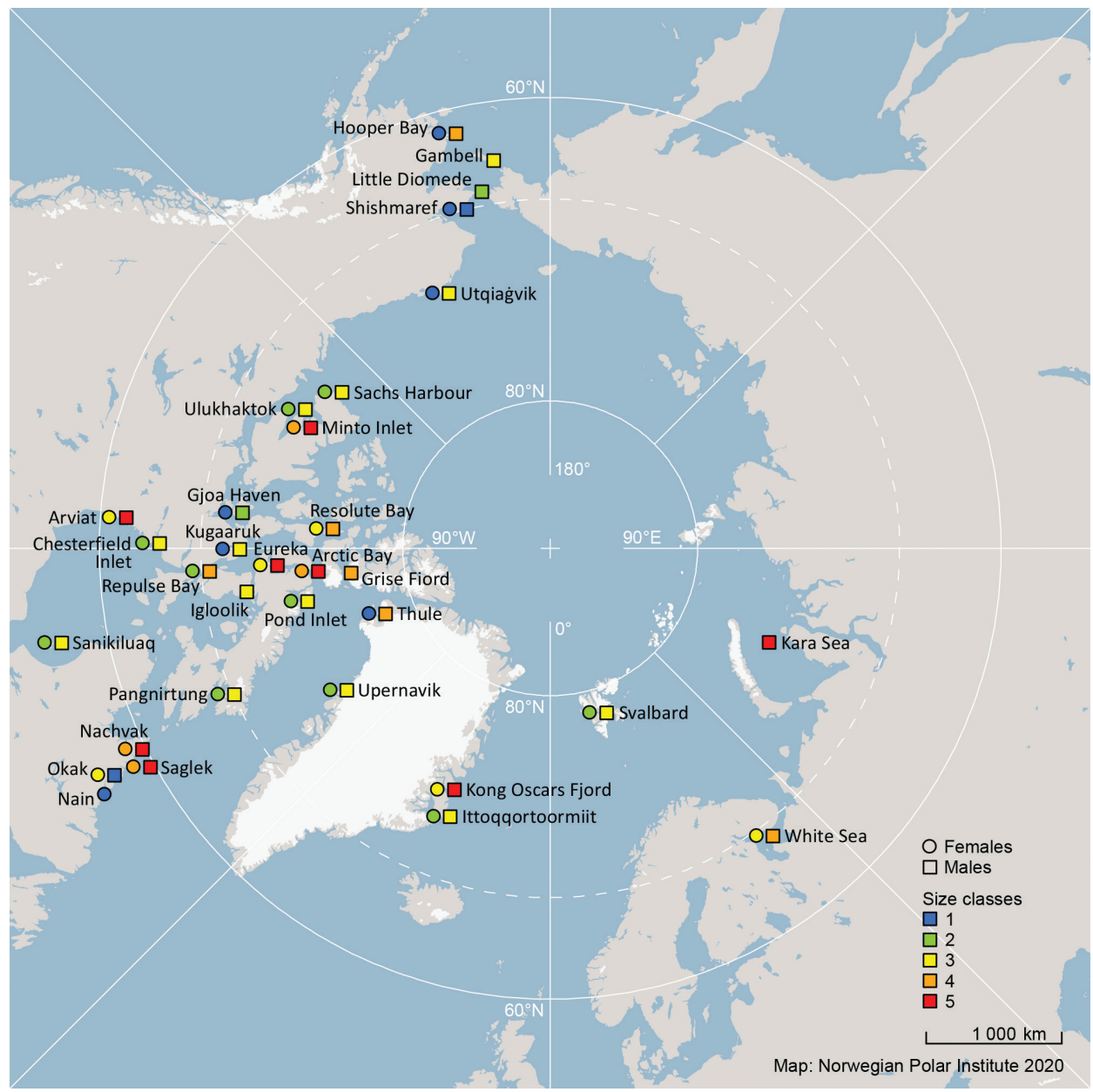

Fig. 2 Ringed seal girth size classes for adult male and adult female ringed seals by sampling location.

Arctic ringed seal subspecies. Davis et al.'s (2008) study of population structure of ice-breeding seals suggested that ringed seals in the White Sea, the smallest seals in the current study, were the only group that was significantly different from all other Arctic subpopulations tested although geographic distances between sampling locations and genetic differences were positively correlated. The overall conclusion by Davis et al. (2008) was that gene flow between areas across the Arctic maintained a homogenized population (outside the White Sea). However, the study had very small sample sizes and used samples collected year-round, including the open-water season, when various populations might share the same foraging ranges, which might have biased their results. Martinez-Bakker et al. (2013) had ringed seal skin samples collected from a more limited study area, representing breeding areas in Alaska and from the western part of the Beaufort Sea, and used the Baltic subspecies as an outgroup. Not surprisingly, the adjacent areas exhibited considerable genetic exchange. However, these authors also concluded that there is regular mixing between the Arctic and Baltic subspecies, despite no documented movements by individuals (in either direction), and the maintenance of marked pelage and skull morphology differences between the subspecies (Amano et al. 2002), and they identified moderate levels of nuclear genetic differentiation.

Adult philopatry to breeding sites seems to be the norm in Arctic ringed seals (e.g., McLaren 1958; Smith \& Hammill 1981; Smith 1987; Krafft et al. 2007; Kelly et al. 2010; Hamilton et al. 2016). Additionally, even though seasonal movements take ringed seals (especially young animals) far from tagging locations in some areas (e.g., Smith 1987; Teilmann et al. 1999; Crawford et al. 2012; Harwood, Smith \& Auld 2012; Hamilton et al. 2015; Yurkowski, Semeniuk et al. 2016), most animals return "home" if the tags work long enough to encompass return migration times, and in some areas, ringed seals are 
Table 5 Cluster assignments of the residual of girth $(\mathrm{cm})$ while accounting for length of ringed seals by location and month of sampling. Residual values indicate if seals have more (positive values) or less (negative values) girth than average given their length and the month of sampling. Dashes denote when there were insufficient data for calculating means. Four clusters explained $96.3 \%$ of the variation in mean residuals for females; five clusters explained $96.4 \%$ of that for males.

\begin{tabular}{|c|c|c|c|c|c|c|}
\hline \multirow[t]{2}{*}{ Location $^{a}$} & \multicolumn{3}{|c|}{ Females } & \multicolumn{3}{|c|}{ Males } \\
\hline & Mean residual (cm) & Cluster number & Cluster mean & Mean residual (cm) & Cluster number & Cluster mean \\
\hline Nain & -9.36 & 1 & -8.06 & - & - & - \\
\hline Hooper Bay & -9.33 & 1 & -8.06 & 2.15 & 4 & 2.31 \\
\hline Little Diomede & - & - & - & -6.65 & 2 & -7.21 \\
\hline Gjoa Haven & -8.97 & 1 & -8.06 & -7.78 & 2 & -7.21 \\
\hline Shishmaref & -8.94 & 1 & -8.06 & -13.07 & 1 & -11.95 \\
\hline Utqiaġvik & -8.07 & 1 & -8.06 & -0.27 & 3 & -2.40 \\
\hline Kugaaruk & -6.36 & 1 & -8.06 & -1.14 & 3 & -2.40 \\
\hline Gambell & - & - & - & -1.79 & 3 & -2.40 \\
\hline Thule (Qaanaaq) & -5.42 & 1 & -8.06 & 3.16 & 4 & 2.31 \\
\hline Igloolik & - & - & - & -3.17 & 3 & -2.40 \\
\hline Ittoqqortoormiit & -3.47 & 2 & -2.23 & -3.53 & 3 & -2.40 \\
\hline Grise Fiord & - & - & - & 1.87 & 4 & 2.31 \\
\hline Sanikiluaq & -3.10 & 2 & -2.23 & -2.92 & 3 & -2.40 \\
\hline Pangnirtung & -2.40 & 2 & -2.23 & -2.94 & 3 & -2.40 \\
\hline Pond Inlet & -2.19 & 2 & -2.23 & -4.41 & 3 & -2.40 \\
\hline Upernavik & -2.16 & 2 & -2.23 & -2.74 & 3 & -2.40 \\
\hline Svalbard & -2.08 & 2 & -2.23 & -3.13 & 3 & -2.40 \\
\hline Sachs Harbour & -1.67 & 2 & -2.23 & -1.67 & 3 & -2.40 \\
\hline Chesterfield Inlet & -1.28 & 2 & -2.23 & -2.31 & 3 & -2.40 \\
\hline Ulukhaktok & -0.80 & 2 & -2.23 & -1.19 & 3 & -2.40 \\
\hline Eureka & 1.21 & 3 & 2.78 & 5.11 & 5 & 6.24 \\
\hline White Sea & 1.45 & 3 & 2.78 & 2.45 & 4 & 2.31 \\
\hline Resolute & 3.39 & 3 & 2.78 & 2.94 & 4 & 2.31 \\
\hline Arviat & 3.50 & 3 & 2.78 & 5.19 & 5 & 6.24 \\
\hline Okak & 3.52 & 3 & 2.78 & -10.83 & 1 & -11.95 \\
\hline Saglek & 7.22 & 4 & 8.52 & 7.18 & 5 & 6.24 \\
\hline Arctic Bay & 8.24 & 4 & 8.52 & 7.16 & 5 & 6.24 \\
\hline Minto & 8.64 & 4 & 8.52 & 8.08 & 5 & 6.24 \\
\hline Nachvak & 9.96 & 4 & 8.52 & 5.10 & 5 & 6.24 \\
\hline
\end{tabular}

a Sample locations are ordered by female residuals and cluster numbers.

resident year round (e.g., Heide-Jørgensen et al. 1992; Harwood et al. 2015; Hamilton et al. 2016; Yurkowski, Semeniuk et al. 2016), though small-scale shifts within regions have been documented among young animals (Luque et al. 2014; Hamilton et al. 2015). The degree to which ringed seals show natal philopatry remains largely unknown. There are records of tagged pups being recaptured/shot where they were born years later (Lydersen $\delta$ Kovacs, unpubl. data), but few records exist because only small numbers of ringed seal pups have been tagged and recaptures are rare. Overall, it seems that Arctic ringed seals have a relatively sedentary nature, with high site fidelity (at least for adults), which is at odds with the two genetics studies that have been published on Arctic ringed seal population structure. However, results from genetics
Table 6 Average age-at-maturity and average length-at-maturity for female ringed seals.

\begin{tabular}{lccc}
\hline Location & $\begin{array}{c}\text { Age-at- } \\
\text { maturity in } \\
\text { years }(95 \% \mathrm{Cl})\end{array}$ & $\begin{array}{c}\text { Length-at-maturity } \\
\text { in cm }(95 \% \mathrm{Cl})\end{array}$ & $\begin{array}{c}\text { \% of final } \\
\text { estimated } \\
\text { body length }\end{array}$ \\
\hline Shishmaref & $3.1(2.3-4)$ & $111.1(106-116.1)$ & 88 \\
Arviat $^{\mathrm{a}}$ & $3.5(-)$ & $102.7(99.8-105.5)$ & 86 \\
Svalbard $_{\text {Sanikiluaq }}$ & $3.9(3.5-4.3)$ & $107.7(104.3-111.0)$ & 82 \\
Kugaaruk $^{\mathrm{a}}$ & $4.3(3.8-4.9)$ & $113.4(111.2-115.6)$ & 91 \\
Pangnirtung & $4.5(-)$ & $115.3(106.4-124.2)$ & 84 \\
Ulukhaktok & $7.4(7.9-5.4)$ & $114.1(109.3-118.9)$ & 86 \\
& & $104.6(103.5-105.7)$ & 85 \\
& & & $\bar{x}(\mathrm{sd})=86.1(2.9)$
\end{tabular}

${ }^{a}$ Cls could not be calculated for the age-at-maturity at Arviat and Kugaaruk because there was no variability in the age at which seals matured. 
research done to date on Arctic ringed seals are not sufficient to make conclusions regarding whether or not there is a genetic basis for the size differences reported in the current study, that is, whether the different groups identified herein are morphs or ecotypes. Tagging studies on ringed seals are unlikely to be sufficiently numerous to answer population structure questions definitively. Thus, research is needed on ringed seal genetics that controls for breeding population, incorporates greater spatial coverage, includes larger sample sizes and ideally utilizes modern high-throughput genetics methods to explore potential population structure across the subspecies' range.

Relative stability of breeding habitats (e.g., drift ice versus shore-fast ice) has been suggested as the determining factor for ringed seal "ecotypes" in previous studies (Fedoseev 1975; Finley et al. 1983; Wiig et al. 1999). The thinking has been that drifting pack ice is a transient platform for breeding compared to shore-fast ice, and that it is likely that pups are more often weaned earlier; at a smaller size in the drifting ice, which influences their final adult body size. Alternatively, the more resourcevariable pack-ice environment might create conditions where small body size is advantageous compared to more stable coastal shore-fast ice habitat (Von Duyke et al. 2020). However, it must be noted that Ferguson et al. (2019) make a case for more variable environments favouring larger body sizes in ringed seals. The current study could not address this hypothesis directly because the sampling regions likely included a mix of pack ice and shore-fast ice breeders in areas where breeding occurs in both habitat types. A related hypothesis is that because land-fast ice is a higher quality habitat, spatial size segregation might arise from larger, more dominant seals displacing smaller subordinate seals from preferred breeding habitat, but such displacements are likely an age-related phenomenon that would not lead to locally adapted ecotypes (see Krafft et al. 2006).

All populations of Arctic ringed seals are exposed to high levels of predation from polar bears (Ursus mariti$m u s)$, and this predator has clearly been a major selective force in the evolution of Arctic ringed seals (e.g., Smith 1980; Gjertz \& Lydersen 1986; Smith \& Lydersen 1991). However, larger body size is highly unlikely to influence predation levels from this vastly larger predator that hunts seals on the ice (including accessing animals in lairs); only vigilance and timely flight allow ringed seals to escape. Bearded seals (Erginathus barbatus), which can weigh seven times as much as ringed seals, and even walruses (Odobenus rosmarus), which can weigh more than a tonne, are also subject to heavy predation from polar bears. Arctic foxes (Vulpes lagopus) are also a major predator of ringed seal pups (Smith 1976; Lydersen \&
Gjertz 1986), particularly when there is little snow cover (Furgal et al. 1996; Iacozza \& Ferguson 2014). Lair characteristics and early development of swimming skills in pups are the primary defences against this predator (see Lydersen \& Hammill 1993). How female ringed seal body size may be related to pup development, and risk of polar bear predation is an open question. Aquatic predation on ringed seals by sleeper sharks (Somniosus microcephalus and S. pacificus; Walter et al. 2017) in the Arctic has recently received considerable attention (Leclerc et al. 2012; MacNeil et al. 2012; McMeans et al. 2013; Lydersen et al. 2016). These small-mouthed, suction-feeding sharks feed on ringed seals in some areas and their success could be influenced by body size of potential prey. However, the density of sleeper sharks and their diets across their range are poorly documented (MacNeil et al. 2012), so it is unclear whether the large size of some ringed seal morphs/ecotypes confers an avoidance advantage with respect to this predator.

Early nutrition is thought to be important to growth rates of seals (Laws 1959; also see Atkinson 1997), and seals reach sexual maturity at about $87 \%$ of their final body length (Laws 1956). Sexual maturity can, therefore, be reached at an earlier age when growth is rapid (e.g. Sergeant 1973). In the present study, size at age-of-maturity was $86.1 \pm 2.8 \%$ of estimated final body size, and populations that reached sexual maturity later generally were larger (also see Harwood et al. 2000; Ferguson et al. 2018). Early break-up of sea ice in spring can result in premature weaning and, hence, poor growth rates and poor survivorship in ringed seals (e.g., Smith \& Harwood 2001; Ferguson et al. 2005; Ferguson et al. 2017). Larger, more rotund seals with excess body fat may be at a disadvantage in warm waters with possible hyperthermic conditions (Ferguson et al. 2017), which could explain the occurrence of smaller seals in southern regions (e.g., Hudson Bay). However, ringed seal body condition is also negatively affected by sea-ice conditions in extremely heavy ice years, presumably indirectly via impacts on their prey species (Stirling et al. 1977; Smith 1987; Stirling 2002; Harwood, Smith, Melling et al. 2012; Crawford et al. 2015; Ferguson et al. 2018; Harwood et al. 2020). In extreme years when break-up is delayed, the proportions of pups in the harvest are reduced in the following year(s) because females either do not ovulate (Harwood, Smith, Melling et al. 2012: Harwood et al. 2020) or pregnancy fails. Three instances of widespread failed ovulation have been documented over the 36-year monitoring series at Ulukhaktok (formerly known as Holman Island; Smith 1987; Kingsley \& Byers 1989; Harwood, Smith, Melling et al. 2012); two of these years had delayed spring break-up, while the third was an average ice year, but it came at the end of six consecutive 
years of reduced body condition (Harwood et al. 2020). This site displays delayed age at sexual maturity $(1.5-2 \times$ that of other areas) and small body size, which suggest resource limitation. This might reflect less favourable feeding conditions in heavy ice years, but a host of other factors might also be linked to severe winter conditions (see Harwood et al. 2012). However, it is noteworthy that girth-to-length ratios were larger at Ulukhaktok compared to some Alaskan or Russian sites, suggesting that harvest levels or density-dependent effects (competition levels) might play a role in addition to ice conditions in size determination and condition levels. Current harvest levels are ca. $10 \%$ of levels sustained by this population in the 1950s, 1960s and 1970s (Smith \& Taylor 1977; Usher 2002; Bell 2012).

Temporal changes in body size of ringed seals over time, linked to local environmental conditions, have been demonstrated in a host of different regions. For example, ringed seals in Alaska currently grow faster, achieve larger final body size and mature at a younger age than they did during 1970-1990 (Crawford et al. 2015). This change is especially true for females. Asymptotic length has increased from $115.8 \mathrm{~cm}(95 \% \mathrm{CI}$ $=114.7-116.9)$ during $1970-1990$ to $123.8 \mathrm{~cm}(95 \% \mathrm{CI}=$ 120.9-127.2) during the period 2000-2012, an increase of approximately $8 \mathrm{~cm}$. Over the same period, age at maturity decreased from $7.3 \pm 0.55$ years to $3.6 \pm 0.87$ years, a decline of about four years. In contrast, the asymptotic length of males has increased by only about $2.7 \mathrm{~cm}$, going from $118.1 \mathrm{~cm}(95 \% \mathrm{CI}=117.1-119.3)$ during $1970-1990$ to $120.8 \mathrm{~cm}(95 \% \mathrm{CI}=118.7-123.4)$ during 2000-2012 in the same study region. This raises the interesting possibility that the growth of females may be more sensitive to environmental changes than that of males, which might help explain the different patterns in body size dimorphism of male and female ringed seals (also see below). Such changes in body size have been documented in response to hunting pressure and resultant population density changes in some seal species. Declines in body size over time have also been detected in harbour seals in Danish and Swedish waters, where population sizes have increased since this species became protected in the mid-1970s (Harding et al. 2018). Some of the most compelling data exist for harp seals (Pagophilus groenlandicus), for which population sizes and commercial takes are well documented (Hammill \& Sauve 2017). In this species, it is also females that are most responsive to density changes; while female condition and size were responsive to density, no clear effects were seen for males over a period with a seven-fold increase in population size (resulting from drastically reduced hunting pressure). Unfortunately, ringed seal population sizes are neither monitored routinely nor are harvests, so it is difficult to explore these relationships in this species. Regardless, body size changes within a region certainly indicate a plastic response by ringed seals to changing environmental or prey density conditions or density-dependent effects. Some exchange across regions might be present in the summer data in this study, which would contribute to increased variability in the regional size assessments. But, the fact remains that the magnitude of differences documented regionally in the current study is much larger than those observed within specific areas over time.

Analyses of girth (relative to length) in the current study confirm that circumference and standard-length tend to track each other in healthy ringed seals. It also confirms the generally rotund body form of Arctic ringed seals. However, there were no consistent patterns beyond males generally being rounder than females at a given site, although there are exceptions even to this. We found that size of seals in neighbouring areas within regions can be significantly different, which suggests that ringed seals depend on quite local resource bases. Variance through time in girth measurements is useful in studies at fine spatial scales exploring body condition in relation to environmental variability (e.g., Harwood et al. 2015; Ferguson et al. 2020; Harwood et al. 2020), climate change and-if data ever become available-population density or prey base information.

Sexual size dimorphism in ringed seals is variable. In six out of 23 sites in the current study, males and females were significantly different; males were significantly larger than females in Ulukhaktok, Sanikiluaq, Repulse Bay, Qeqertarssuaq/Disko Bay and Uummannaq, and females were significantly larger than males in Svalbard. Given that ringed seals mate in the water and females occur at relatively low densities, large body size among males almost certainly has fewer advantages compared to land-breeding seals (Bartholomew 1970), although ringed seals are thought to be somewhat polygynous and have the potential to fast (or at least endure periods with reduced food intake) for males is likely advantageous during breeding, when they are defending underwater territories (Kelly \& Wartzok 1996; Krafft et al. 2007; Yurkowski et al. 2011; but also see Ferguson et al. 2019).

If the differences in size observed in this study do have a genetic basis, it would be interesting to know what mix of selective pressures are driving size differentiation. Perhaps there is a selective advantage to growing slowly to a large body size in unpredictable environments. McLaren (1993) suggested that extreme environments in the High Arctic were correlated with high variability in size; but, in his study, this high variation occurred specifically in areas where a mix of pack-ice breeding and landfast ice breeding seals were likely to occur. Sea-ice habitats 
at higher latitudes have traditionally been characterized by shorter ice-free seasons and higher levels of interannual variation in the duration of the ice-free season (e.g., Yurkowski, Ferguson et al. 2016; Ferguson et al. 2020). However, dramatic changes in the Arctic gateway of the Atlantic sector are resulting in dramatic reductions in sea ice in the Barents Sea region, whereas other Arctic areas are thus far less influenced, creating a highly variable pattern of ice phenologies that has yet to be carefully analysed with respect to ringed seal habitats (see Laidre et al. 2015). Ecosystem responses to declining sea ice are expected to vary regionally (e.g., Kovacs et al. 2011). If local ecotypes of Arctic ringed seals do exist, they are likely to be affected differently by climate warming, which might provide some species-level resistance to ongoing habitat changes.

In summary, ringed seals show considerable variation in body size across their range, and there are recognizable regional morphs; but the drivers of the observed patterns are not understood, and they are likely to be complex and highly variable on relatively small spatial scales. Marked differences in girths (controlled for length) at neighbouring sites suggest that ringed seals likely depend on food resources that are local. Although this study included data from across much of the circumpolar range of ringed seals, available data from many sites were few (and Russian data are almost non-existent), despite large subsistence harvests in many areas, necessitating the use of variable methods to estimate asymptotic lengths. Few monitoring programmes exist for ringed seals and most of those that do struggle to maintain time series. Harvests are poorly documented in many regions, and population sizes and trends are largely unknown (CAFF 2017). Despite many attempts to establish circumpolar monitoring of ringed seals, there is not a single country that has taken up this challenge with committed long-term programmes. As a start point, genetics studies need to be conducted to confirm whether the very large seals in western Greenland and the eastern Canadian Arctic do constitute real ecotypes adapted to local conditions. Additional research should target the influences of predation, habitat variation and prey availability for ringed seals across appropriate geographic and temporal scales to explore the impacts of these drivers on body size, survival rates and other aspects of the ecology of this important Arctic-endemic pinniped. Such research is essential to determine if the broad range in sizes observed in this study reflects responses to environmental variation (morphs and plasticity) or truly represents an example of adaptation to local conditions (ecotypes). Future research will also help us predict how this species is likely to respond to climate change in the decades ahead. Ringed seals are showing some dietary flexibility in response to changing prey bases (e.g., Crawford et al. 2015; Yurkowski, Ferguson et al. 2016; Lowther et al. 2017; Boucher et al. 2020), although traditional prey types are still favoured despite declines in their abundance (Bengtsson et al. 2020). In some areas, ringed seals are exhibiting behavioural plasticity in dealing with ice reductions (e.g., Hamilton et al. 2015; Yurkowski, Ferguson et al. 2016; Yurkowski, Semeniuk et al. 2016; Lydersen et al. 2017). However, in areas of the Arctic where declines in sea ice have been greatest, ringed seals seem to be retracting into Arctic refugia areas (Hamilton et al. 2019). Demographic modelling coupled to ice and snow forecasts suggests that ringed seals will decline substantially by the year 2100 (Reimer et al. 2019). However, a greater understanding of population structure, trends, regional responses to declining sea ice, and shifting food webs among morphs or ecotypes of ringed seals are needed to make more informed predictions for the future of this Arctic "sentinel" species.

\section{Acknowledgements}

In Alaska, the authors appreciate the partnership with seal hunters and their communities for access to samples and the support for monitoring by the Ice Seal Committee and the North Slope Borough. Marine mammal samples were collected under the US National Marine Fisheries Service research permits 358-1585, 358-1787 and 15324. The authors thank Anna Bryan, Letty Hughes, Mark Nelson and Gay Sheffield for assistance in field collection, and Louise Biderman, Andrew Brenner, Juan Leon Guerrero and Heidi Isernhagen for sample processing. Many colleagues have contributed to the sampling in Greenland and are all acknowledged together with the Greenlandic Inuit hunters. The authors also thank indigenous hunters and the hunters and trappers associations, organizations and committees across the Canadian Arctic who helped with regional collections. From Ulukhaktok, Sachs Harbour and Minto Inlet, NT, the authors gratefully acknowledge the late Jimmy Memogana, the late Morris Nigiyok, David Kuptana, Jeff Kuptana, Tim Byers, John Alikamik, Emma Alikamik and Harold Wright. The authors also thank the late Michael C.S. Kingsley for his role in the earlier years of the seal monitoring programme in the western Canadian Arctic. The authors also thank Gregory W. Theimann (York University) for facilitating some of the eastern Canadian collections. In Norway and Russia, scientific field teams that helped with collections are also thanked.

\section{Disclosure statement}

The authors report no conflict of interest. 


\section{Funding}

In Alaska, funding was provided by the National Oceanic and Atmospheric Administration, National Marine Fisheries Service under awards NA16FX2034, NA05NMF4391187, NA08NMF4390544 and NA1 lNMF4390200 to the Alaska Department of Fish and Game, with additional funding in 2002-05 from the North Pacific Research Board (project no. 312). Recent Greenlandic sampling was funded by the Danish Cooperation for Environment in the Arctic of the Danish Environmental Protection Agency. The early ringed seal sampling in the 1980s in Greenland was supported by the Commission for Scientific Research in Greenland and the Danish National Science Foundation. Support for the annual field and laboratory work in Canada's western Arctic was provided by the Fisheries Joint Management Committee established under the Inuvialuit Final Agreement, and by the Department of Fisheries and Oceans. Funding for Canadian work in eastern Canada was provided by the Nunavut General Monitoring Plan, Nunavut Wildlife Management Board, Fisheries and Oceans Canada, Environment and Climate Change Canada, Northern Contaminants Program (CrownIndigenous Relations and Northern Affairs Canada), ArcticNet Centre of Excellence, Natural Sciences and Engineering Research Council of Canada Discovery Grants, W. Garfield Weston Foundation and the Molson Foundation. The Norwegian Polar Institute, the Svalbard Environmental Protection Fund and the Norwegian Research Council provided financial support for studies in Norway, and the Murmansk Marine Biological Institute supported Russian data collection.

\section{References}

Amano M., Hayano A. \& Miyazaki N. 2002. Geographic variation in the skull of the ringed seal Pusa hispida. Journal of Mammalogy 83, 370-380, doi: 10.1644/1545-1542(2002)0 83<0370:GVITSO>2.0.CO;2.

Atkinson S. 1997. Reproductive biology of seals. Reviews of Reproduction 2, 175-194, doi: 10.1530/ror.0.0020175.

Bartholomew G.A. 1970. A model for the evolution of pinniped polygyny. Evolution 24, 546-559, doi: 10.2307/2406835.

Bell R.K. 2012. A review of seal harvests in the Inuvialuit Settlement Region, NWT. Report for the Fisheries Joint Management Committee. Inuvik, NT: Fisheries Joint Management Committee.

Bengtsson O., Lydersen C., Kovacs K.M. \& Lindström U. 2020. Ringed seal (Pusa hispida) diet on the west coast of Spitsbergen, Svalbard, Norway: during a time of ecosystem change. Polar Biology 43, 773-788, doi: 10.1007/ s00300-020-02684-5.

Blackburn T.M. \& Gaston K.J. 1994. Animal body size distributions: patterns, mechanisms and implications.
Trends in Ecology and Evolution 9, 471-474, doi: 10.1016/ 0169-5347(94)90311-5.

Blackburn T.M., Gaston K.J. \& Loder N. 1999. Geographic gradients in body size: a clarification of Bergmann's rule. Diversity and Distributions 5, 165-174, doi: 10.1046/ j.1472-4642.1999.00046.x.

Boucher N.P., Nichole P., Derocher A.E. \& Richardson E.S. 2020. Spatial and temporal variability in ringed seal (Pusa hispida) stable isotopes in the Beaufort Sea. Ecology and Evolution 10, 4178-4192, doi: 10.1002/ece3.6186.

Burnham K.P. \& Anderson D.R. 2003. Model selection and multimodel inference: a practical information-theoretic approach. Cham: Springer Nature.

CAFF 2017. State of the Arctic marine biodiversity report. Akureyri: Conservation of Arctic Flora and Fauna International Secretariat.

Calder W.A. 1984. Size, function, and life history. Cambridge, MA: Harvard University Press.

Crawford J.A., Frost K.J., Quakenbush L.T. \& Whiting A. 2012. Different habitat use strategies by subadult and adult ringed seals (Phoca hispida) in the Bering and Chukchi seas. Polar Biology 35, 241-255, doi: 10.1007/ s00300-011-1067-1.

Crawford J.A., Quakenbush L.T. \& Citta J.J. 2015. A comparison of ringed and bearded seal diet, condition and productivity between historical (1975-1984) and recent (2003-2012) periods in the Alaskan Bering and Chukchi seas. Progress in Oceanography 136, 133-150, doi: 10.1016/j. pocean.2015.05.011.

Davis C.S., Stirling I., Stobeck C. \& Coltman D.W. 2008. Population structure of ice-breeding seals. Molecular Ecology 17, 3078-3094, doi: 10.1111/j.1365-294X.2008.03819.x.

Dietz R., Heide-Jørgensen M.-P., Teilmann J., Valentin N. \& Härkönen T. 1991. Age determination in European harbour seals Phoca vitulina L. Sarsia 76, 17-21, doi: 10.1080/0 0364827.1991 .10413461$.

Fedoseev G.A. 1975. Ecotypes of the ringed seal (Pusa hispida Schreber, 1777) and their reproductive capabilities. Rapports et Procès-Verbaux des Reunions du Conseil International pour l'Exploration de la Mer 169, 156-160.

Ferguson S.H., Stirling I. \& McLoughlin P. 2005. Climate change and ringed seal (Phoca hispida) recruitment in western Hudson Bay. Marine Mammal Science 21, 121-135, doi: $10.1111 /$ j.1748-7692.2005.tb01212.x.

Ferguson S.H., Xinhua Z., Young B.G., Yurkowski D.J., Thiemann G.W., Fisk A.T. \& Muir D.C.G. 2018. Geographic variation in ringed seal growth rate and body size. Canadian Journal of Zoology 96, 649-659, doi: 10.1139/cjz-2017-0213.

Ferguson S.H., Young B.G., Yurkowski D.J., Anderson R., Willing C. \& Nielsen O. 2017. Demographic, ecological, and physiological responses of ringed seals to an abrupt decline in sea ice availability. PeerJ 5, e2957, doi: 10.7717/ peerj.2957.

Ferguson S.H., Yurkowski D.J., Young B.G., Fisk A.T., Muir D.C.G., Zhu X. \& Thiemann G.W. 2020. Comparing temporal patterns in body condition of ringed seals living within their core geographic range with those living at the edge. Ecography 43, 1521-1535, doi: $10.1111 /$ ecog.04988. 
Ferguson S.H., Yurkowski D.J., Young B.G., Willing C., Zu Z.H., Muir D.C.G., Fisk A.T. \& Thiemann G.W. 2019. Do intraspecific life history patterns follow interspecific predictions? Population Ecology 61, 371-382, doi: 10.1002/ 1438-390X.12008.

Finley K.J., Miller G.W., Davis R.A. \& Koski W.R. 1983. A distinctive large breeding population of ringed seals (Phoca hispida) inhabiting the Baffin Bay pack ice. Arctic 36, 162-173.

Furgal C.M., Kovacs K.M. \& Innes S. 1996. Characteristics of ringed seal, Phoca hispida, subnivean structures and breeding habitat and their effects on predation. Canadian Journal of Zoology 74, 858-874, doi: 10.1139/z96-100.

Gaston K.J. 2000. Global patterns in biodiversity. Nature 405 , 220-227, doi: 10.1038/35012228.

Gelman A., Carlin J.B., Stern H.S. \& Rubin D.B. 2003. Bayesian data analysis. 2nd edn. Boca Raton, FL: CRC Press.

Gelman A., Huang J. \& Vehtari A. 2014. Understanding predictive information criteria for Bayesian models. Statistics and Computing 24, 997-1016, doi: 10.1007/s1 1222-013-9416-2.

Gjertz I. \& Lydersen C. 1986. Polar bear predation on ringed seals in the fast-ice of Hornsund, Svalbard. Polar Research 4 , 65-68, doi: 10.3402/polar.v4il.6921.

Hamilton C.D., Lydersen C., Ims R.A. \& Kovacs K.M. 2015. Predictions replaced by facts in a changing Arctic: a keystone species' behavioural responses to declining sea ice. Biology Letters 11, article no. 20150803, doi: 10.1098/ rsbl.2015.0803.

Hamilton C.D., Lydersen C., Ims R.A. \& Kovacs K.M. 2016. Coastal habitat use by ringed seals Pusa hispida following a regional sea-ice collapse: importance of glacial refugia in a changing Arctic. Marine Ecology Progress Series 545, 261-277, doi: 10.3354/meps 11598.

Hamilton C.D., Vacquié-Garcia J., Kovacs K.M., Ims R.A., Kohler J. \& Lydersen C. 2019. Contrasting responses to climate change by two Arctic marine mammal species. Biology Letters 15, article no. 20180834, doi: 10.1098/ rsbl.2018.0834.

Hammill M.O. \& Sauvé C. 2017. Growth and condition in harp seals: evidence of density-dependent and density-independent influences. ICES Journal of Marine Sciences 74, 1395-1407, doi: 10.1093/icesjms/fsw237.

Harding K.C., Salmon M., Teilmann J., Dietz R. \& Härkönen T. 2018. Population wide decline in somatic growth in harbour seals-early signs of density dependence. Front Ecology and Evolution 6, article no. 59, doi: 10.3389/ fevo.2018.00059.

Hartigan J.A. \& Wong M.A. 1979. Algorithm AS 136: a k-means clustering algorithm. Applied Statistics 28, 100108, doi: 10.2307/2346830.

Harwood L.A., Smith T.G., Alikamik J., Lea E.V., Stirling I., Wright H., Melling H. \& Zhu X. 2020. Long-term, harvest-based monitoring of ringed seal body condition and reproduction in Canada's western Arctic: an update through 2019. Arctic 73, 206-220, doi: 10.14430/arctic70428.

Harwood L.A., Smith T.G. \& Auld J.C. 2012. Fall migration of ringed seals (Phoca hispida) through the Beaufort and Chukchi seas, 2001-02. Arctic 65, 35-44, doi: 10.14430/ arctic4163.
Harwood L.A., Smith T.G., Auld J.C., Melling H. \& Yurkowski D.J. 2015. Seasonal movements and diving of ringed seals, Pusa hispida, in the western Canadian Arctic, 1999-2001 and 1020-11. Arctic 68, 193-209, doi: 10.14430/arctic4479.

Harwood L.A., Smith T.G. \& Melling H. 2000. Variation in reproduction and body condition of the ringed seal (Phoca hispida) in western Prince Albert Sound, NT, Canada, as assessed through a harvest-based sampling program. Arctic 53, 422-431, doi: 10.14430/arctic872.

Harwood L.A., Smith T.G., Melling H., Alikamik J. \& Kingsley M.C.S. 2012. Ringed seals and sea ice in Canada's western Arctic: harvest-based monitoring 1992-2011. Arctic 65, 377-390, doi: 10.14430/arctic4236.

Heide-Jørgensen M.P., Stewart B.S. \& Leatherwood S. 1992. Satellite tracking of ringed seals Phoca hispida off northwest Greenland. Ecography 15, 56-61, doi: 10.1111/j.16000587.1992.tb00008.x.

Holst M. \& Stirling I. 2002. A comparison of ringed seal (Phoca hispida) biology on the east and west sides of the North Water Polynya, Baffin Bay. Aquatic Mammals 28, 221-230.

Holst M., Stirling I. \& Calvert W. 1999. Age structure and reproductive rates of ringed seals (Phoca hispida) on the northwestern coast of Hudson Bay in 1991 and 1992. Marine Mammal Science 15, 1357-1364, doi: 10.1111/ j.1748-7692.1999.tb00898.x.

Hooten M.B. \& Hobbs N.T. 2015. A guide to Bayesian model selection for ecologists. Ecological Monographs 85, 3-28, doi: 10.1890/14-0661.1.

Iacozza J. \& Ferguson S.H. 2014. Spatio-temporal variability of snow over sea ice in western Hudson Bay, with reference to ringed seal pup survival. Polar Biology 37, 817-832, doi: 10.1007/s00300-014-1484-z.

Katsanevakis S. 2006. Modelling fish growth: model selection, multi-model inference and model selection uncertainty. Fisheries Research 81, 229-235, doi: 10.1016/j. fishres.2006.07.002.

Kellner K. 2019. jagsUI: a wrapper around "rjags" to streamline "JAGS" analyses. R package version 1.1.1. Accessed on the internet at https://CRAN.R-project.org/package=jagsUI

Kelly B.P. \& Wartzok D. 1996. Ringed seal diving behaviour in the breeding season. Canadian Journal of Zoology 74, 1547-1555, doi: 10.1139/z96-169.

Kelly B.P., Badajos O.H., Kunnasranta M., Moran J.R., Martinez-Bakker M., Wartzok D. \& Boveng P. 2010. Seasonal home ranges and fidelity to breeding sites among ringed seals. Polar Biology 33, 1095-1109, doi: 10.1007/ s00300-010-0796-x.

Kingsley M.C.S. \& Byers T.J. 1998. Failure of reproduction in ringed seals (Phoca hispida) in Amundsen Gulf, Northwest Territories in 1984-1987. In M.P. Heide-Jørgensen \& C. Lydersen (eds.): Ringed seals of the North Atlantic. NAMMCO Scientific Publications 1. Pp. 197-210. Tromsø: North Atlantic Marine Mammal Commission.

Kleiber M. 1975. The fire of life. An introduction to animal energetics. Huntington, NY: Kreiger Publishing Company.

Kovacs K.M., Lydersen C., Overland J.E. \& Moore S.E. 2011. Impacts of changing sea-ice conditions on Arctic 
marine mammals. Marine Biodiversity 41, 181-194, doi: 10.1007/s12526-010-0061-0.

Krafft B.A., Kovacs K.M., Frie A.K., Haug T. \& Lydersen C. 2006. Growth and population parameters of ringed seals (Pusa hispida) from Svalbard, Norway, 2002-2004. ICES Journal of Marine Sciences 63, 1136-1 144, doi: 10.1016/j. icesjms.2006.04.001.

Krafft B.A., Kovacs K.M. \& Lydersen C. 2007. Distribution of sex and age groups of ringed seals Pusa hispida in the fast-ice breeding habitat of Kongsfjorden, Svalbard. Marine Ecology Progress Series 355, 199-206, doi: 10.3354/ meps335199.

Laidre K.L., Stern H., Kovacs K.M., Lowry L., Moore S.E., Regehr E.V., Ferguson S.H., Wiig Ø., Boveng P., Angliss R.P., Born E.W., Litovka D., Quakenbush L., Lydersen C., Vongraven D. \& Ugarte F. 2015. Arctic marine mammal population status, sea ice habitat loss, and conservation recommendations for the 21 st century. Conservation Biology 29, 724-737, doi; 10.1111/cobi.12474.

Laws R.M. 1956. Growth and sexual maturity in aquatic mammals. Nature 178, 193-194, doi: 10.1038/178193a0.

Laws R.M. 1959. Accelerated growth in seals, with special reference to the Phocidae. Norsk Hvalfangst-Tidende 48, 425-452.

Leclerc L-M.E., Lydersen C., Haug T., Bachmann L., Fisk A.T. \& Kovacs K.M. 2012. A missing piece in the Arctic food web puzzle? Stomach contents of Greenland sharks sampled in Svalbard, Norway. Polar Biology 35, 1197-1208, doi: 10.1007/s00300-012-1166-7.

Lindstedt S.L. \& Boyce M.S. 1985. Seasonality, fasting endurance and body size in mammals. American Naturalist 125 , 873-878, doi: 10.1086/284385.

Lowry D.B. 2012. Ecotypes and the controversy over stages in the formation of new species. Biological Journal of the Linnean Society 106, 241-257, doi: 10.1111/j.1095-8312. 2012.01867.x.

Lowry L. 2016. Pusa hispida. The IUCN Red List of Threatened Species 2016: e.T41672A45231341. Accessed on the internet at https://doi.org/10.2305/IUCN.UK.2016-1.RLTS. T41672A45231341.en on 1 November 2020.

Lowther A., Fisk A., Kovacs K.M. \& Lydersen C. 2017. Interdecadal changes in the marine food web along the west Spitsbergen coast detected in the stable isotope composition of ringed seal whiskers. Polar Biology 40, 20272033, doi: 10.1007/s00300-017-2122-3.

Luque S.P. \& Ferguson S.H. 2010. Age structure, growth, mortality and density of belugas (Delphinapterus leucas) in the Canadian Arctic: responses to environment? Polar Biology 33, 163-178, doi: 10.1007/s00300-009-0694-2.

Luque S., Ferguson S.H. \& Breed G. 2014. Spatial behaviour of a keystone Arctic marine predator and implications of climate warming in Hudson Bay. Journal of Experimental Marine Biology and Ecology 461, 504-515, doi: 10.1016/j. jembe.2014.10.002.

Lydersen C., Fisk A.T. \& Kovacs K.M. 2016. A review of Greenland shark (Somniosus microcephalus) studies in the Kongsfjorden area, Svalbard Norway. Polar Biology 39, 2169-2178, doi: 10.1007/s00300-016-1949-3.
Lydersen C. \& Gjertz I. 1986. Studies of the ringed seal (Phoca hispida Schreber 1775) in its breeding habitat in Kongsfjorden, Svalbard. Polar Research 4, 57-63, doi: 10.3402/polar.v4il.6920.

Lydersen C. \& Gjertz I. 1987. Population parameters of ringed seals (Phoca hispida, Schreber, 1775) in the Svalbard area. Canadian Journal of Zoology 65, 1021-1027, doi: 10.1139/ z87-162.

Lydersen C. \& Hammill M.O. 1993. Diving in ringed seal (Phoca hispida) pups during the nursing period. Canadian Journal of Zoology 71, 991-996, doi: 10.1139/Z93-131.

Lydersen C., Vaquie-Garcia J., Lydersen E., Christensen G.N. \& Kovacs K.M. 2017. Novel terrestrial haul-out behaviour by ringed seals (Pusa hispida) in Svalbard, in association with harbour seals (Phoca vitulina). Polar Research 36, article no. 1374124, doi: 10.1080/17518369.2017.1374124.

MacNeil M.A., McMeans B.C., Hussey N.E., Vercsei P., Svavarsson J., Kovacs K.M., Lydersen C., Treble M.A., Skomal G.B., Ramsey M. \& Fisk A.T. 2012. Biology of the Greenland shark Somniosus microcephalus. Journal of Fish Biology 80, 991-1018, doi: 10.1111/j.1095-8649.2012.03257.x.

Mansfield A.W. 1967. Seals of Arctic and eastern Canada. Fisheries Research Board of Canada Bulletin 137. Ottawa: Fisheries Research Board of Canada.

Martinez-Bakker M.E., Sell S.K., Swanson B.J., Kelly B.P. \& Tallmon D.A. 2013. Combined genetic and telemetry data reveal high rates of gene flow, migration, and long-distance dispersal potential in Arctic ringed seals (Pusa hispida). PLoS One 8, e77125. doi: 10.1371/journal.pone.0077125.

McLaren I.A. 1958. The biology of the ringed seal, Phoca hispida, in the eastern Canadian Arctic. Bulletin of the Fisheries Research Board of Canada 118. Ottawa: Fisheries Research Board of Canada.

McLaren I.A. 1993. Growth in pinnipeds. Biological Reviews of the Philosophical Society 68, 1-79, doi: 10.1111/j.1469185x.1993.tb00731.x.

McMeans B.C., Aarts M.T., Lydersen C., Kovacs K.M., Hop H., Falk-Petersen S. \& Fisk A.T. 2013. The role of Greenland sharks (Somniosus microcephalus) in an Arctic ecosystem: assessed via stable isotopes and fatty acids. Marine Biology 160, 1223-1238, doi: 10.1007/s00227-013-2174-z.

Panik M.J. 2014. Growth curve modeling: theory and applications. Hoboken, NJ: John Wiley \& Sons.

Pauly D. 1981. The relationships between gill surface area and growth performance in fish: a generalization of von Bertalanffy's theory of growth. Berichte der Deutschen Wissenchaftlichen Kommission für Meeresforschung 28, 251-282.

Peters R.H. 1983. The ecological implications of body size. Cambridge: Cambridge University Press.

Pilford N.W., Derocher A.E., Stirling I. \& Richardson E. 2014. Polar bear predatory behaviour reveals seascape distribution of ringed seal lairs. Population Ecology 56, 129-138. doi: 10.1007/s10144-013-0396-z.

Plummer M. 2019. rjags: Bayesian graphical models using MCMC. R package version 4-10. Accessed on the internet at https://CRAN.R-project.org/package=rjags

Quinn T.J. \& Deriso R.B. 1999. Quantitative fish dynamics. Oxford: Oxford University Press. 
R Core Team 2020. R: a language and environment for statistical computing. Vienna: R Foundation for Statistical Computing. Reimer J.R., Caswell H., Derocher A.E. \& Lewis M.A. 2019. Ringed seal demography in a changing climate. Ecological Applications 29, e01855, doi: 10.1002/eap.1855.

Rosing-Asvid A. 2010. Seals of Greenland. Gylling, Denmark: Narayana Press.

Ryg M., Smith T.G. \& Øristsland N.A. 1990. Seasonal changes in body mass and body compositions of ringed seals (Phoca hispida) on Svalbard. Canadian Journal of Zoology 68, 470-475, doi: 10.1139/z90-069.

Schnute J.T. \& Richards L.J. 1990. A unified approach to the analysis of fish growth, maturity, and survivorship data. Canadian Journal of Fisheries and Aquatic Sciences 47, 24-40, doi: 10.1139/f90-003.

Sergeant D.E. 1973. Feeding, growth and productivity in the Northwest Atlantic harp seal (Pagophilus groenlandicus). Journal of the Fisheries Research Board of Canada 30, 17-29, doi: 10.1139/f73-003.

Sibly R.M. \& Brown J.H. 2007. Effects of body size and lifestyle on evolution of mammal life histories. Proceedings of the National Academy of Sciences 104, 17707-17712, doi: 10.1073/pnas.0707725104.

Smith T.G. 1973. Population dyna mics of the ringed seal in the Canadian eastern Arctic. Fisheries Research Board of Canada Bulletin 181. Ottawa: Fisheries Research Board of Canada.

Smith T.G. 1976. Predation of ringed seal pups (Phoca hispida) by the Arctic fox (Alopex lagopus). Canadian Journal of Zoology 54, 1610-1616, doi: 10.1139/z76-188.

Smith T.G. 1980. Polar bear predation of ringed and bearded seals in the land-fast sea ice habitat. Canadian Journal of Zoology 58, 2201-2209, doi: 10.1139/z80-302.

Smith T.G. 1987. The ringed seal, Phoca hispida, of the Canadian western Arctic. Canadian Bulletin of Fisheries and Aquatic Sciences 216. Ottawa: Department of Fisheries and Oceans.

Smith T.G. \& Hammill M.O. 1981. Ecology of the ringed seal, Phoca hispida, in its fast-ice breeding habitat. Canadian Journal of Zoology 59, 966-981, doi: 10.1139/z81-135.

Smith T.G. \& Harwood L.A. 2001. Observations of neonate ringed seals, Phoca hispida, after early break-up of the sea ice in Prince Albert Sound, Northwest Territories, Canada, spring 1998. Polar Biology 24, 215-219, doi: 10.1007/ s003000000198h.

Smith T.G. \& Lydersen C. 1991. Availability of suitable land-fast ice and predation as factors limiting ringed seal populations, Phoca hispida, in Svalbard. Polar Research 10, 585-594, doi: 10.3402/polar.v10i2.6769.

Smith T.G. \& Taylor D. 1977. Notes on marine mammal, fox and polar bear harvests in the Northwest Territories 1940 to 1972. Fisheries and Marine Services Technical Report 694. Ottawa: Environment Canada.

Stirling I. 2002. Polar bears and seals in the eastern Beaufort Sea and Amundsen Gulf: a synthesis of population trends and ecological relationships over three decades. Arctic 55 Suppl. 1, 59-76.

Stirling I., Archibald W.R. \& DeMaster D.P. 1977. Distribution and abundance of seals in the eastern Beaufort Sea.
Journal of the Fisheries Research Board of Canada 34, 976-988, doi: 10.1139/f77-150.

Teilmann J., Born E.W. \& Acquarone M. 1999. Behaviour of ringed seals tagged with satellite transmitters in the North Water Polynya during fast-ice formation. Canadian Journal of Zoology 77, 1934-1946, doi: 10.1139/z99-163.

Tikhomirov E.A. 1971. Body growth and development of reproductive organs of the North Pacific phocids. In V.A. Arseniev \& K.I. Panin (eds.): Pinnipeds of the North Pacific. Pp. 213-241. Jerusalem: Israel Program for Scientific Translations.

Turesson G. 1922. The species and the variety as ecological units. Hereditas 3, 100-113, doi: 10.1111/j.1601-5223.1922. tb02727.x.

Usher P.J. 2002. Inuvialuit use of the Beaufort Sea and its resources, 1960-2000. Arctic 55 Suppl. 1, 18-28.

Vehtari A., Gabry J., Yao Y. \& Gelman A. 2018. loo: efficient leave-one-out cross-validation and WAIC for Bayesian models. R package version 2.0.0. Accessed on the internet at https://CRAN.R-project.org/package=loo

Vehtari A., Gelman A. \& Gabry J. 2017. Practical Bayesian model evaluation using leave-one-out cross-validation and WAIC. Statistics and Computing 27, 1413-1432, doi: 10.1007/s1 1222-016-9696-4.

Von Bertalanffy L. 1938. A quantitative theory of organic growth (inquiries on growth laws. II). Human Biology 10, $181-213$.

Von Duyke A.L., Douglas D.C., Herreman J.K. \& Crawford J.A. 2020. Ringed seal (Pusa hispida) seasonal movements, diving and haulout behavior in the Beaufort, Chukchi, and Bering seas (2011-2017). Ecology and Evolution 10, 5595-5616, doi: 10.1002/ece3.602.

Walter R.P., Roy D., Hussey N.E., Stelbrink B., Kovacs K.M., Lydersen C., McMeans B.C., Svavarsson J., Kessel S.T., Porsmoguer S.B., Wildes S., Tribuzio C., Campana S.E., Petersen S., Grubbs R.D., Heath D.D., Hedges K.J. \& Fisk A.T. 2017. Origins of the Greenland shark (Somniosus microcephalus): impacts of ice-olation and introgression. Ecology and Evolution 7, 8113-8125, doi: 10.1002/ece3.3325.

Watanabe S. 2010. Asymptotic equivalence of Bayes cross validation and widely applicable information criterion in Singular Learning Theory. Journal of Machine Learning Research 11, 3571-3594.

Wiig Ø., Derocher A.E. \& Belikov S.I. 1999. Ringed seal (Phoca hispida) breeding in the drifting pack ice of the Barents Sea. Marine Mammal Science 15, 595-598, doi: 10.1111/ j.1748-7692.1999.tb00828.x.

Young B.G. \& Ferguson S.H. 2013. Seasons of the ringed seal: pelagic open-water hyperphagy, benthic feeding over winter and spring fasting during molt. Wildlife Research 40, 52-60, doi: 10.1071/WR12168.

YurkowskiD.J., ChambellantM.\& Ferguson S.H.2011.Bacular and testicular growth and allometry in the ringed seal (Pusa hispida): evidence of polygyny? Journal of Mammalogy 92, 803-810, doi: 10.1644/10-MAMM-A-082.1.

Yurkowski D.J., Ferguson S.H., Semeniuk C.A.D., Brown T.M., Muir D.C.G. \& Fisk A.T. 2016. Spatial and temporal variation of an ice-adapted predator's feeding ecology in a 
changing Arctic marine ecosystem. Oecologia 180, 631-644, doi: 10.1007/s00442-015-3384-5.

Yurkowski D.J., Semeniuk C.A.D., Harwood L.A., Rosing-Asvid A., Dietz R., Brown T.M., Clackett S.,
Grgicak-Mannion A., Fisk A.T. \& Ferguson S.H. 2016. Influence of sea ice phenology on the movement ecology of ringed seals across their latitudinal range. Marine Ecology Progress Series 562, 237-250, doi: 10.3354/meps 11950. 